\title{
IMÁGENES ETNOGRÁFICAS: REPRESENTACIÓN Y DISCURSO DEL “INDIO” EN CHILE EN LA OBRA DE FRAY DIEGO DE OCAÑ ${ }^{*}$
}

\author{
ETHNOGRAPHIC IMAGES: REPRESENTATION AND SPEECH ON “THE \\ INDIAN” IN CHILE IN THE WORK OF FRAY DIEGO DE OCAÑA
}

\author{
Viviana Gallardo Porras **
}

\begin{abstract}
Se analiza la parte que corresponde a Chile en la preciada relación de viaje de Fray Diego de Ocaña. En su relato confluyen las características de una relación de viaje, con las exigencias históricas de una crónica. La pretensión de narrar hechos, es acompañada por dibujos y acuarelas, testimonio de aquello visto y presenciado. Este artículo indaga en la correspondencia del texto con la imagen y en la construcción de alteridad que se despliega textual e iconográficamente para representar al indio. Se afirma que el texto de Ocaña trata de representaciones que se superponen en un relato de corte épico y que se mueve en una constante tensión: reconocer la fuerza e ímpetu indígena y conocer otras realidades indígenas que el territorio le muestra. Se concluye que existe una concordancia entre texto e imagen, que complementan y refuerzan la idea central de la obra surgida en "tierra de guerra".

Palabras claves: Viajeros, indígenas, iconografía, representación.
\end{abstract}

This article analyses the Chilean part of the journey of Fray Diego de Ocaña. His account brings together the characteristics of a travel journal as well as the historical precisions of a chronicle. The intention of recalling events is combined with sketches and paintings, as a testimony of what has been seen and experienced. The article analyses the links between text and images and the construction of otherness in the textual and iconographic representations of the Indian. It affirms that Ocaña's text deals with representations that are superimposed upon an epic-like tale in constant tension: recognizing indigenous strength and motivation, and knowing other indigenous realities that are present in the territorial space. The conclusion is that there is a concordance between text and image that complements and reinforces the central idea of the work based on a "land at war".

Key words: Travelers, indigenous, iconography, representation.

\section{Introducción}

Fray Diego de Ocaña salió en 1599 del convento de Guadalupe en Extremadura hacia América, iniciando un recorrido por estas tierras que se prolongó hasta 1605. Su traslado a América obedeció a una misión de evangelización: construir o iniciar en este continente el culto a la virgen de Guadalupe. Ocaña vino con el encargo de recabar limosnas entre los devotos de la virgen y de asegurar que estas limosnas llegasen a la península. Su viaje pasó por el istmo de Panamá y por el Virreinato del Perú, el cual recorrió desde Payta hasta la isla de Chiloé, desde la Patagonia hasta Paraguay y desde Tucumán hasta el altiplano boliviano ${ }^{1}$. El Viaje de Ocaña tuvo un sentido misional. De su recorrido es producto una interesante relación de viaje, en ella el fraile despliega sus dotes de literato, historiador, pintor y cronista. Al respecto, Amalia
Iniesta (2004) sugiere que su relato es, ante todo, la construcción de un itinerario narrativo-descriptivo al servicio de la Virgen de Guadalupe. La autora define la narración de Ocaña como viaje religioso o memoria religiosa.

El viaje por territorio chileno comenzó en Coquimbo hacia el 1600. El contexto histórico reciente y de grandes repercusiones en la gobernación, sin duda fue Curalaba (alzamiento indígena de 1598 en el cual el propio gobernador Martín García Oñez de Loyola perdió la vida) ${ }^{2}$. El historiador Álvaro Jara señala que, con posterioridad a Curalaba, en España, se temió seriamente por la pérdida de Chile

\footnotetext{
"todo el mundo construido por los españoles comenzaba a caer, demolido precisamente por aquellos indios que eran el estrato inferior e indispensable de la construcción" (Jara 1984:126).
}

\footnotetext{
* Resultado del proyecto Núcleo temático de Investigación Relatos de viajeros: ¿Los otros discursos sobre “los indios”, Universidad Academia de Humanismo Cristiano.

** Universidad Academia de Humanismo Cristiano, Santiago, Chile. Correo electrónico: vivianaxgp@ hotmail.com
} 
El poder español desde el Bío Bío al sur se desmoronó, quedando en ruinas ciudades y fuertes, los cuales fueron arrasados por los indígenas. Las ciudades y lavaderos del sur se perdieron, la actividad aurífera fue aniquilada, tierras, ganados y casas fueron destruidos, el territorio se redujo, la frontera se estableció en el río Bío Bío, el esfuerzo fundacional decayó, el territorio chileno se encontraba alzado y se consolidó como "tierra de guerra". "Perdido el presente y perdido el futuro, el mundo se cerraba sobre medio reino" (Jara 1984:127).

En ese contexto y como producto de su itinerario, Diego de Ocaña redactó un preciado documento, una relación del viaje a tierras americanas que consta de 360 folios. Publicado en forma fragmentaria en varias ocasiones, la parte que corresponde a Chile comprende desde la página $70 \mathrm{v}$, hasta la página $109 \mathrm{v}$ en que cruza la cordillera para ir a Tucumán (Pereira Salas 1995: 20-21) ${ }^{3}$.

Notoria e interesante en esta obra es la inserción de ilustraciones y dibujos realizados a pluma y coloreados a mano. Las explicaciones de los dibujos se insertan en forma independiente al resto del relato. Las piezas iconográficas relativas a Chile cuentan 11 más un mapa dividido en 4 hojas. Son representaciones de indígenas e hispanos y algunos animales característicos de la tierra. Cada una de estas imágenes tiene inserto un escrito, como diría Barthes, un mensaje lingüístico que permite identificar lo retratado, constituyendo una descripción denotada de la imagen (Barthes 1963:36).

El conocimiento estético y científico de la naturaleza y habitantes de estos territorios se deriva de la observación directa y atenta de Ocaña, quien testimonia: "por ser esto lo mejor de todo Perú y tierra firme iré por el camino con el papel en la mano marcando y pintando toda la tierra" (Ocaña 1995:32 [1600] $)^{4}$.

Es precisamente en esta misma época -la modernidad temprana- cuando se produce en Europa un cambio de actitud frente al registro gráfico, a partir del cual los textos fueron entendidos como representaciones. En este nuevo modo de escribir, leer y dibujar, se suponía que las expresiones debían ser tomadas literalmente, como si no significaran ni más ni menos que lo que decían. A diferencia del discurso medieval, en el cual "un hablante decía algo para que se comprendiera otra cosa" (Olson 1999:222).

La imagen gráfica -el dibujo, la pintura y el grabado-fueron asumidos como representaciones y ya no como artefactos mnemotécnicos para recordar temas clásicos. Como representaciones de cosas visibles en el mundo, la atención del dibujante o grabadista, estuvo centrada en la pretensión de construir una representación correcta más que objetos de interpretación. Así, la producción gráfica se convirtió en un fiador de lo visto, que fue incluida incipientemente en los textos durante el siglo XVII.

La pintura, el dibujo y el grabado fueron en esta época las formas más importantes y trascendentales (tal vez las únicas) de producir imagen, de dejar testimonio, de graficar aquello supuestamente visto. El arte como tal cumplió un rol de testigo y traductor de experiencias de viajeros, cartógrafos y cronistas y, por su parte, influyó con códigos estéticos y contenidos a la producción de imágenes. Tal es el caso de algunas relaciones, crónicas o historias del siglo XVII que insertan imágenes junto a su relato. Contamos entre ellas la obra de Alonso Ovalle, Histórica Relación del Reyno de Chile y de las missiones y ministerios que exercita en él la Compañía de Jesús, publicada en 1648 y Antonio de Herrera en su texto Historia general de los hechos de los castellanos en las islas y tierra firme del mar océano, publicada entre 1601 y 1615. Posteriormente se encuentra la obra titulada Compendio de la historia geográfica, natural y civil del Reyno de Chile, del jesuita expulso abate Juan Ignacio Molina, editada en Italia en 1776, escrita casi de memoria pues el manuscrito le fue requisado en el Callao cuando salía al exilio. En todas estas obras, podemos reconocer al indígena como un motivo a representar. Estas imágenes las nominamos "etnográficas", pues pretenden representar al mundo indígena, su apariencia, atuendos o costumbres ${ }^{5}$. Reconocemos en estas obras que los temas representados se relacionan principalmente con: indígenas individuales, acontecimientos bélicos y costumbres 6 .

Igual que en estas crónicas e Historia Natural, las imágenes producidas por Ocaña no fueron representaciones gráficas aisladas o independientes. Se insertaron y acompañaron un texto. El autor itinerante tuvo especial cuidado por ofrecer a sus lectores una narración y descripción de las tierras americanas y de sus habitantes, profundizando con la incorporación de imágenes, dibujos, mapas, en fin, aspectos iconográficos que además completó en el lenguaje escrito. Su texto guarda un orden narrativo cronológico y espacial, que lo vincula al 
relato de viaje con las posibilidades retóricas de este modelo.

La organización del relato se efectúa en función del itinerario seguido por el autor. (...) aquel itinerario es una suerte de convocatoria para el lector. (...) para que participe de las alternativas del viaje... (Odone 2008:22).

Entendiendo que cada producción narrativa tiene sus propias exigencias, las cuales determinan el discurso y las formas de representación, nos es imprescindible detenernos en analizar qué tipo de narración colonial es la producida por Ocaña.

\section{Sobre la representación textual}

Lo que se ha denominado narrativa colonial hispanoamericana está constituida por una serie de producciones que podríamos sintetizar en cartas, crónicas y relaciones del descubrimiento y la conquista. En ellas se advierte el relato del encuentro y percepción de América y sus habitantes por parte de los europeos. Con distintas motivaciones y propósitos, estos textos fueron construyendo diversos discursos sobre la conquista y colonización, lo que sin duda incidió en la percepción y descripción de América y los americanos 7 . Tal como plantea Olson, las producciones textuales pueden ser concebidas como una metáfora,

(...) apta para analizar las implicancias de la cultura escrita, dado que mediante la creación de textos que funcionan como representaciones, es posible abordar el mundo tal como es copiado o descrito (Olson 1999:221).

Creados en los siglos XVI al XVIII, estas producciones textuales estuvieron construidas de acuerdo al pensamiento de su época. En el caso específico de la obra de Ocaña -como para todas las obras más tempranas-, una época entre épocas. Cronológicamente en la modernidad, pero con la persistencia de elementos medievales, del renacimiento y de incipientes pretensiones ilustradas. Así confluyeron en la representación de lo americano, los seres fantásticos con la visión religiosa, apariencias de estética clásica y una ingenua pretensión de mostrar el mundo tal y como es. El reconocer y conocer fue la tensión permanente en estos textos (Lira 2004).

Walter Mignolo (1982) ha definido y caracterizado la narrativa colonial y, a través de su análisis, podemos aproximarnos al conocimiento de las exigencias de la época para representar a través del texto (sobre el papel) la realidad observada.

En cuanto representación textual, aquello que se enuncia y conoce como Relación fue definido por el Diccionario de Autoridades como "la narración o información que se hace de alguna cosa que sucedió" (Real Academia Española 1737: 556). Una de sus principales características es que ellas no transcriben la observación libre de lo que ve quien escribe, sino que responde, de alguna manera, a ciertos pedidos oficiales (Mignolo 1982). Necesario es recordar que el origen de este tipo de documento procede de la iniciativa del Consejo de Indias en 1571 para elaborar un libro descriptivo de todas las provincias indianas. A partir de ese momento se elaboraron y enviaron a América cuestionarios en donde se solicitaba información sobre: clima, calidad de la gente, descripción del suelo, riquezas minerales, etc. Para Mignolo (1982) las relaciones se ajustan a un modelo creado sobre la marcha y "están basados sobre las necesidades que emanan de la información que se desea obtener" (Mignolo 1982:73). Una de las características principales de las Relaciones es haber sido encargadas a hombres de letras y en su estructura narrativa responden a una necesidad de recoger y ordenar la información sobre las nuevas tierras conquistadas.

Otro representante de la narrativa colonial corresponde a lo que se denomina Historia o en otras ocasiones se identifica con el vocablo Crónica. ¿A qué clase de discurso alude? ¿Cuáles son las exigencias de su narración? En este tipo de narrativa colonial confluyen dos vocablos Historia y Crónica. El primero, haciendo alusión a un informe de lo visto o lo aprendido por medio de las preguntas, en ningún momento incorpora el elemento temporal. Así, por ejemplo, la historia natural se ajusta a esa definición. La Crónica, en cambio, es el vocablo para denominar el informe del pasado o la anotación de los acontecimientos del presente fuertemente estructurados por la secuencia temporal (Mignolo 1982). En el momento en que ambos vocablos coexisten surge ese tipo de narración que pretende contar hechos verdaderos no solo sujetos a la temporalidad sino, también, en tanto discurso histórico, a las exigencias de la retórica. 
El fin de escribir Historia es -desde Aristótelesocuparse de verdades particulares; así entonces, este tipo de texto pretende narrar o contar los acontecimientos dignos de memoria, resaltar hazañas propias o ajenas y en un escenario de conquista y colonización -como lo era América-, los insumos fueron cuantiosos: la fundación de ciudades, el avance en el territorio, el enfrentamiento con los indios, la actitud heroica, el despliegue de astucia y energía de ambos bandos, etc.

Este tipo de narración se sometió a los criterios de verdad vigentes en su época. Fiadora del relato verdadero era, por ejemplo, la supuesta presencia del narrador o cronista en los hechos relatados o en el paisaje descrito. Las fórmulas de verdad eran las de "lo visto y oído" y aquello que "por mis propios pies anduve". La propia experiencia del cronista era el eje ordenador del relato, pudiendo ser éste cronológico y/o geográfico.

La presencia actúa como validador de fiabilidad y eje en el desarrollo de los acontecimientos a través de un narrador que participa, estableciendo los estatutos de lo verdadero y lo cierto... (Martínez 2000:34).

No en muchas ocasiones la pretensión de realidad en estas narraciones estuvo acompañada por imágenes, dibujos o acuarelas que se desplegaban como testimonio o elemento validador de aquello visto y presenciado. La obra de Ocaña es un raro ejemplo de ello. Sus imágenes fueron parte integrante del relato; sin embargo, sería simplificar el análisis concebir a esas imágenes como un mero reflejo de las ideas expuestas en el texto (Fayet 2006). Es necesario, por tanto, indagar sobre la posible correspondencia entre texto e imagen y advertir qué intensidad de diálogo existió entre ellos. Además y en relación a la representación del indio, es pertinente analizar si efectivamente se expresa esa posible correspondencia en la construcción de alteridad. Más aún, sería pertinente identificar cuál es la construcción de alteridad que se despliega textual e iconográficamente para representar al indio.

\section{Sobre la narración y descripción}

López de Mariscal y Madroñal señalan que el texto es mucho más que un relato de viaje, este incorpora además relaciones de sucesos como por ejemplo lo sucedido en los terremotos de Arequipa de 1600 y 1604, la descripción de las fiestas que se realizaron con motivo de la entronización de la Virgen en las ciudades de La Plata, Charcas y Potosí, y la inclusión de una comedia titulada Comedia de Nuestra Señora de Guadalupe y sus milagros, además de veintidós dibujos y cinco mapas (Mariscal y Madroñal 2010:17). Sin embargo, para efectos de la presente investigación, es preciso aclarar que nuestro análisis trata sobre un fragmento de esta obra, que corresponde al viaje de fray Diego de Ocaña por el actual territorio chileno, es en este fragmento en el cual podemos distinguir que confluyen en él las características de Relación de viaje y de Crónica.

En tanto Relación, presenta una estructura narrativa de relato de viaje, organizándose en función del itinerario seguido por el autor, así, este va informando y tomando nota de todo aquello que se observa. Ocaña actuó a la manera de un naturalista, puesto que durante el viaje tomó datos, esbozó figuras, describió la tierra y dibujó mapas del territorio.

Su viaje a Chile comenzó con su desembarco en Coquimbo. De ahí siguió el viaje a lo largo del territorio. El esqueleto narrativo de su obra lo da la geografía. Define a Copiapó como comienzo de la gobernación, en los $27^{\circ}$, pasando luego a las ciudades de Coquimbo y Santiago. Es minucioso en dar las características de la tierra: latitud, minerales, climas y descripción de valles. Así también, la presencia de conventos y frailes es una constante en su relato. Desde Santiago se dirige a la ciudad de Chillán "toda tierra llana y muy poblada de indios los cuales se llaman indios promaucaes" (Ocaña 1995:33 [1600]). Hasta aquí es tierra de paz; de Chillán en adelante enuncia "indios de guerra".

A partir de Chillán, Ocaña divide la descripción, pierde la linealidad que entrega la geografía y bifurca el relato en dos caminos: uno hacia Concepción, el otro hacia Angol. Estas localidades se constituyen en puntos de descripción. Ambas son "tierra de guerra". Angol es "tierra fría y de grandes vientos", conventos de pocos frailes ocupan el sector. En Concepción, en cambio, hay numerosos conventos, esta ciudad es frontera de guerra con los indios del valle de Arauco. Del valle de Arauco dice ser el mejor que tiene esta tierra de guerra, es muy poblado. Ocaña evoca un hecho en que destaca a dos protagonistas indios: Lautaro y Caupolicán. Su narración es casi en presente: 
(...) Caupolicán que era cacique principal del valle de Arauco y el que había muerto al Valdivia nombró por su teniente a Lautaro que fue criado y yanacona del mismo Valdivia que se habia pasado a los indios de guerra. (Ocaña 1995: 35-36 [1600]).

La exigencia de la Crónica aparece en la memoria y el recuerdo de hazañas pasadas, de los hechos y sujetos dignos de memoria.

De aquí en adelante, la descripción geográfica se desordena o pierde algo de su estructura. Geográficamente avanza y retrocede. Esta alteración del esquema narrativo obedece a la pulcritud e intención puesta por el autor en describir las acciones de guerra. Caracteriza primero el territorio de Concepción a Imperial, afirmando que es toda la fuerza de la guerra de Chile. Luego de Angol a Imperial. Se detiene a describir minuciosamente una quebrada muy honda que a su juicio es lugar ideal para que los indios preparen sus emboscadas:

(...) y cuando los españoles están abajo salen los indios a ellos de emboscada, y por ser el sitio estrecho y fragoso que no se pueden aprovechar de los caballos han muerto a muchos españoles (Ocaña 1995:39 [1600]).

Es notorio como Ocaña sostiene que la geografía colabora con la guerra a favor de los indios. En otro lugar se lee: "y así son estos indios muy belicosos por esta ocasión que tienen desta fortaleza desta laguna que la naturaleza parece que puso allí para defensa suya" (Ocaña 1995:39 [1600]). Y, sin embargo, con anterioridad el fraile había referido causas de tipo cultural para explicar la dilatada guerra de Chile:

De Chillán a Chiloé habitan en las montañas sin tener pueblo formado sino en sus chacaras y sementeras y esta es la causa porqué es esta tierra tan difícil de conquistar, por las muchas emboscadas que hacen porque ellos nunca se juntan en escuadrones formados... (Ocaña 1995:37[1600]).

La habilidad para emboscar asignada a los indios es destacada por Ocaña, así como las costumbres guerreras. Los considera indios de razón y traza, en particular para las cosas de la guerra y, más abajo, advierte que sus costumbres son buenas porque acostumbran ocuparse en el ejercicio de la guerra.

Su avance en el territorio continúa por Valdivia, Osorno, Villarrica y Chiloé. Retoma el esquema narrativo, enunciando su ubicación en grados, calidad de la tierra, cantidad de población y presencia de conventos. La enunciación indígena es "indios de la tierra". Sin embargo, algo que llama poderosamente la atención es la nominación de "gente muy cobarde" para los habitantes de las islas aledañas a Chiloé. Son estas muy pobladas de indios de paz, refiere Ocaña. En esta alusión existe una notoria sobrevaloración a la destreza bélica, a la capacidad y disposición guerrera que han mostrado aquellos indios nombrados anteriormente como "indios de guerra". Símbolo de la situación actual de la gobernación, se constituyen los indios de guerra en protagonistas del relato. Ocaña culmina el viaje por territorio chileno haciendo mención a las islas australes hasta el Estrecho de Magallanes. Clausura la narración con la mención a gigantes que posiblemente habitan esta zona (Ocaña 1995:41 [1600]). Cabe destacar la persistencia del imaginario sobre los supuestos gigantes australes, el cual pasó a América en los primeros años del descubrimiento y conquista (Rojas Mix 1993: 138-146) ${ }^{8}$.

Hasta aquí la enunciación sobre "lo indio". Mezcla y rescate de elementos y recursos narrativos medievales, renacentistas e ilustrados. Los gigantes, seres fantásticos, se cuelan en la obra de Ocaña, que hasta ese momento de la narración había mostrado celo y apego a la realidad observada. Sin duda y pese a ello, la carga que manifiesta en la descripción y representación de los indios de guerra, tiene, además, una connotación fuertemente medieval. Es la persistencia de motivos caballerescos. Durante el renacimiento, la caballería siguió significando para la aristocracia un mundo admirable, épico-ideal; este imaginario llenó cuadros, tapices y grabados (Hauser 2002). La representación iconográfica de los escogidos por Ocaña como modelos de la destreza guerrera indígena, aparecen en su obra con casco de tres o cuatro plumas. Tal como advierte Pereira Salas (1995), este símbolo parece tener un significado constante, pues lo aplica indistintamente a los jefes españoles y aborígenes. El casco coronado con plumas es similar al yelmo medieval. El indio, aunque descalzo, es vestido con armaduras y cascos. Para los indios, el peto de cuero, arco, lanza y a veces macana completan el cuadro. Fisonomías españolas clásicas y atuendos guerreros indígenas 
integran la imagen. Ocaña seleccionó y adoptó un estereotipo de guerrero, adaptándolo a la función de su relato e incorporándole rasgos distintivos, es decir, generando un estereotipo adaptado. En este punto concordamos con Gombrich (2002), al señalar que en la producción artística no se parte de una impresión visual, sino de una idea, de un concepto. De esta manera, la información visual específica, vale decir, los rasgos distintivos se apuntan en una especie de modelo preexistente.

\section{Sobre las representaciones visuales ${ }^{9}$}

La obra de Ocaña, como hemos manifestado, se sujeta a un modelo descriptivo acerca del territorio y sus habitantes. La condición de relato de viaje se expresa en la descripción ordenada geográficamente de lo que el paisaje americano le muestra. Sin embargo, existe en el relato una mirada historizante dada por su carácter de Crónica. Notorio ejemplo de ello es la mención a guerreros araucanos como Caupolicán y Lautaro. Ellos son perfectamente identificados y nombrados, evocando hechos pasados e insertando en la descripción de Arauco a estos dos protagonistas indios:

Deste valle fue el más valeroso indio que ha habido en Chile que fue Caupolicán. De aquí fue también natural Lautaro, los cuales vencieron al Gobernador Valdivia y le mataron a él y a toda su gente al dicho valle (Ocaña 1995:36 [1600]).

Incluso son representados visualmente. Caupolicán (ver Figura 1) es insertado en la descripción del valle de Arauco. Es representado como un guerrero con lanza y macana, incluye además un arco. Su apariencia es corpulenta, Ocaña advierte "que son más corpulentos y más fornidos que los demás que son como manchegos de España" (Ocaña 1995: 58 [1600]).

Principal atención pone Ocaña en el traje de guerra. La representación de un indio de la ciénaga de Purén ${ }^{10}$, que es ataviado con los símbolos guerreros, así lo demuestra: coraza de cuero de vaca, casco coronado de plumas, lanza. Como advertimos más arriba, el valor guerrero es exaltado por Ocaña y las características de destreza física y astucia se reflejan en la representación visual. Más aún, en el texto identifica un supuesto argumento indígena de la mantenida guerra de Arauco: "son indios de

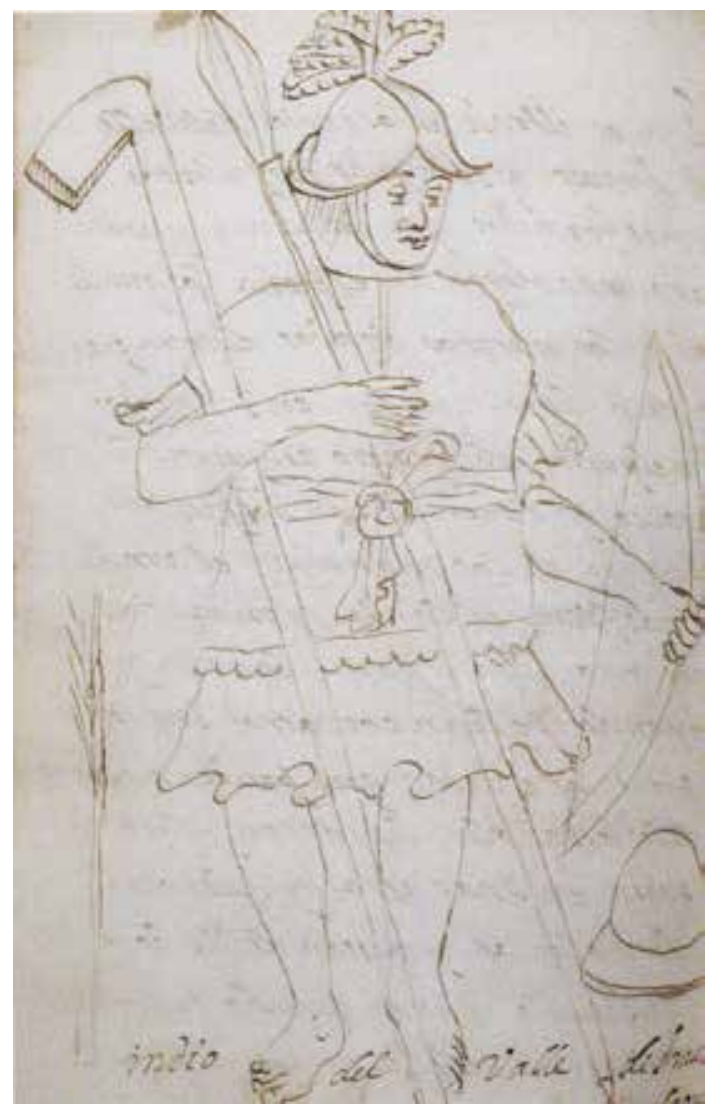

Figura 1. Fray Diego de Ocaña. Indio del valle de Arauco. Caupolicán. Este mató al gobernador Valdivia.

mucha razón; sustentan la guerra por no servir a los españoles diciendo que la naturaleza los hizo libres como a ellos" (Ocaña 1995:58 [1600]).

Lautaro es otro representante del valle de Arauco (ver Figura 2). Él mató al gobernador Valdivia. Su apariencia y traje es similar al de los indios de la ciénaga de Purén, incluso en la pose, también con casco con plumas y coraza de cuero, agrega arco y macana.

Este indio Lautaro que está aquí pintado fue el que mato a toda la gente de Villagrán que fueron casi 300 hombres los muertos. Era indio muy valiente y por eso le eligieron por su capitán. Era natural del Valle de Arauco y como ellos andan ansi los he pintado para llevarlo todo (Ocaña 1995:59 [1600]).

El único representado sobre caballo es Anganamón (ver Figura 3.), quien dio muerte al 


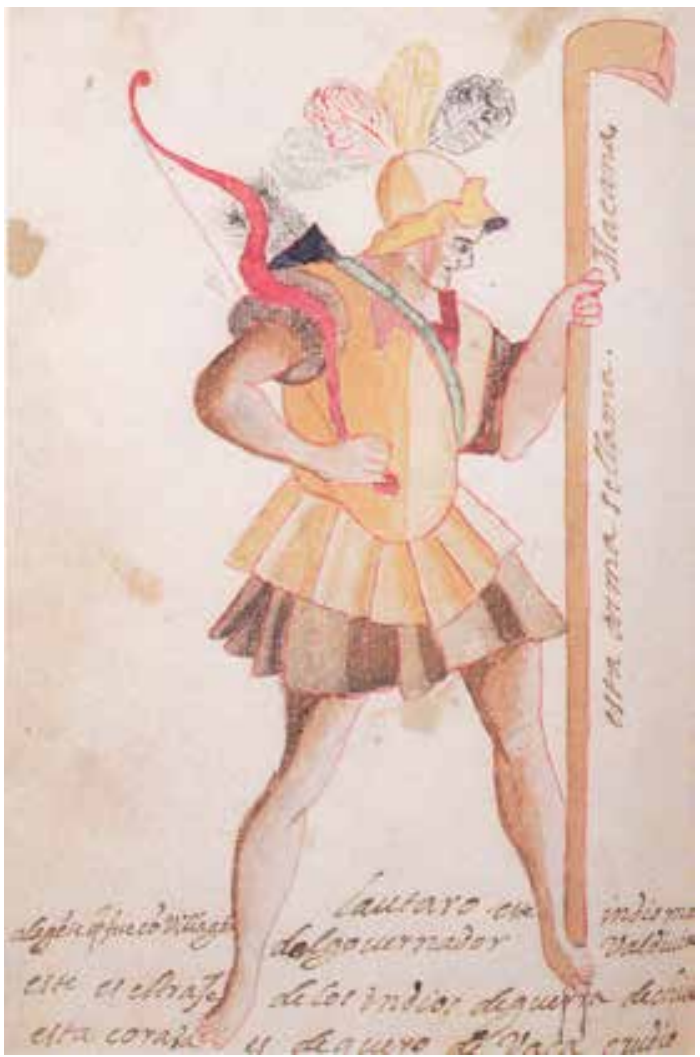

Figura 2. Fray Diego de Ocaña. Lautaro. Este indio mató a la gente que fue con Villagrán, del gobernador Valdivia. Este es el traje de los indios de Chile: esta coraza es de cuero de vaca crudío. Esta arma se llama macana.

Gobernador Martín García de Loyola y se enfrentó posteriormente a Alonso de Sotomayor. Es este indio contemporáneo a los hechos de Curalaba y al propio Ocaña. Anganamón es dibujado en igualdad de condiciones con el español: caballo, lanza, casco, escudo. Sin duda, iconográficamente, no hay diferencias aparentes entre hispanos e indígenas ${ }^{11}$. El texto que sirve de explicación al dibujo entrega características de este indio a saber: robusto, doblado y fuerte y no grande de cuerpo. Es soberbio y pelea con el español aunque este venga a caballo.

Las representaciones hispanas son las de los gobernadores Martín García de Loyola y Alonso de Sotomayor, que como expresamos no difieren en lo absoluto con la representación de Anganamón (ver Figuras 4 y 5).

A estos dibujos etnográficos se agregan otros tres que refieren a la mujer indígena. La representación femenina es solo indígena, no

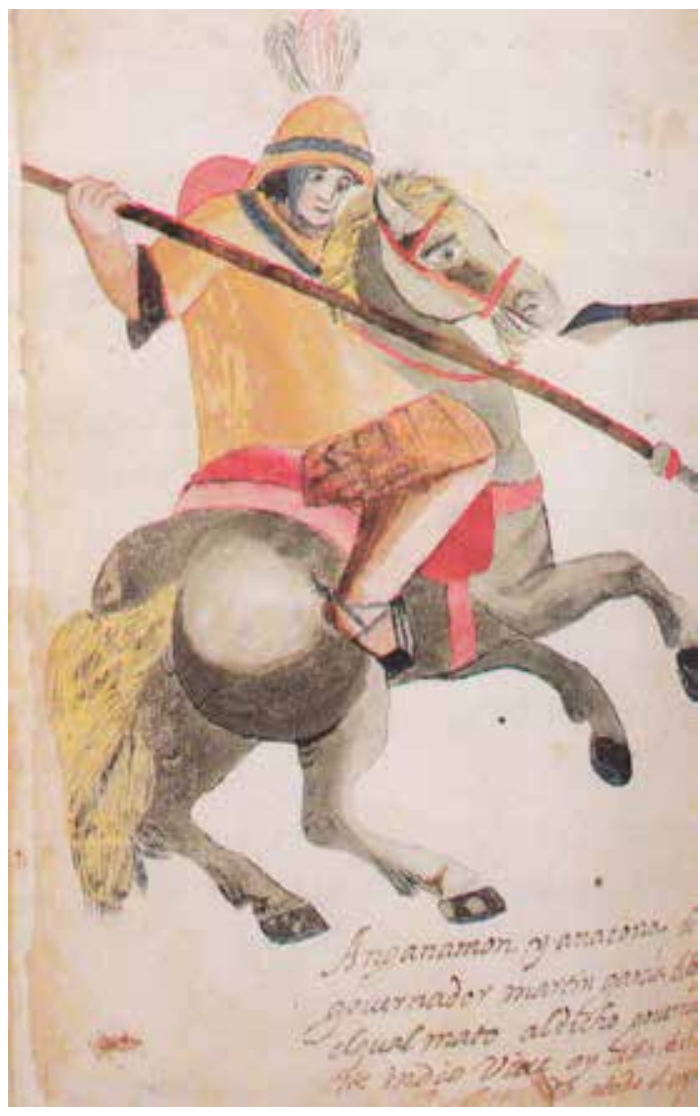

Figura 3. Fray Diego de Ocaña. Anganamón, yanacona del Gobernador Martín García de Loyola, el cual mató al dicho Gobernador. Este indio vive hoy, año de 1607, y es el que ha destruido todo el reyno.

tiene contraparte con la hispana. Y en apariencia la motivación o interés de Ocaña es describir a la mujer indígena en un "así son las indias de la tierra" (Ocaña 1995:75 [1600]). Principal preocupación entrega al traje y atuendos, diferenciando entre las indias de los llanos con las del valle de Arauco. Así también Guacolda se convierte en la representante "del traje de las chilenas desde Coquimbo hasta el valle de Arauco" (Ocaña 1995:75 [1600]). Sin embargo, siguiendo la serie de representaciones visuales y su correspondiente explicación textual, Ocaña entrega veladamente mayor información sobre las indias. Para el caso de las indias de los llanos (ver Figura 6), estas, dice el cronista-pintor, visten generalmente de negro, no utilizan adornos en sus vestimentas y llevan el pelo negro, largo y suelto sobre los hombros, lo que las hace parecer a su juicio "demonios y brujas" (Ocaña 1995: 56 [1600]). 


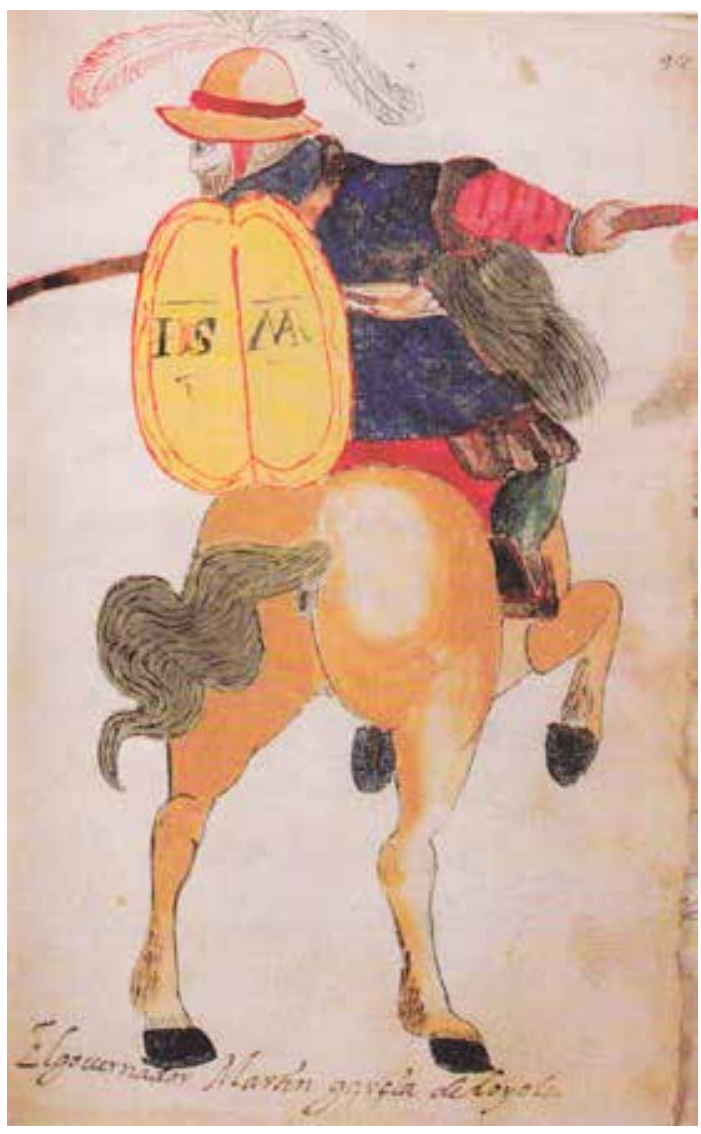

Figura 4. Fray Diego de Ocaña. El Gobernador Martín García de Loyola.

Refiere además a sus escasos hábitos de aseo, nominándolas puercas, "porque si no es cuando se ven juntos a la mar no se lavan y en casa tienen manos y las caras puercas..." (Ocaña 1995: 57 [1600]). Agrega que se emborrachan con chicha y duermen como puercos todos juntos en el suelo. "Y así la hija no está segura del padre ni la hermana del hermano porque ansí ellas como ellos todos están borrachos porque comen poco y beben mucho" (Ocaña 1995: 57 [1600]).

Esta trilogía femenina continúa con la mujer del valle de Arauco (ver Figura 7), en tanto la representación visual y textual refieren a lo mismo: su traje en forma detallada y quehacer propios de su género como es el hilado. Incluye además en el texto una alusión a su virtud, en tanto son casadas "no admiten más que al marido" (Ocaña 1995: 58 [1600]).

Mientras más próxima al grupo guerrero, pareciera que la representación de la india es más

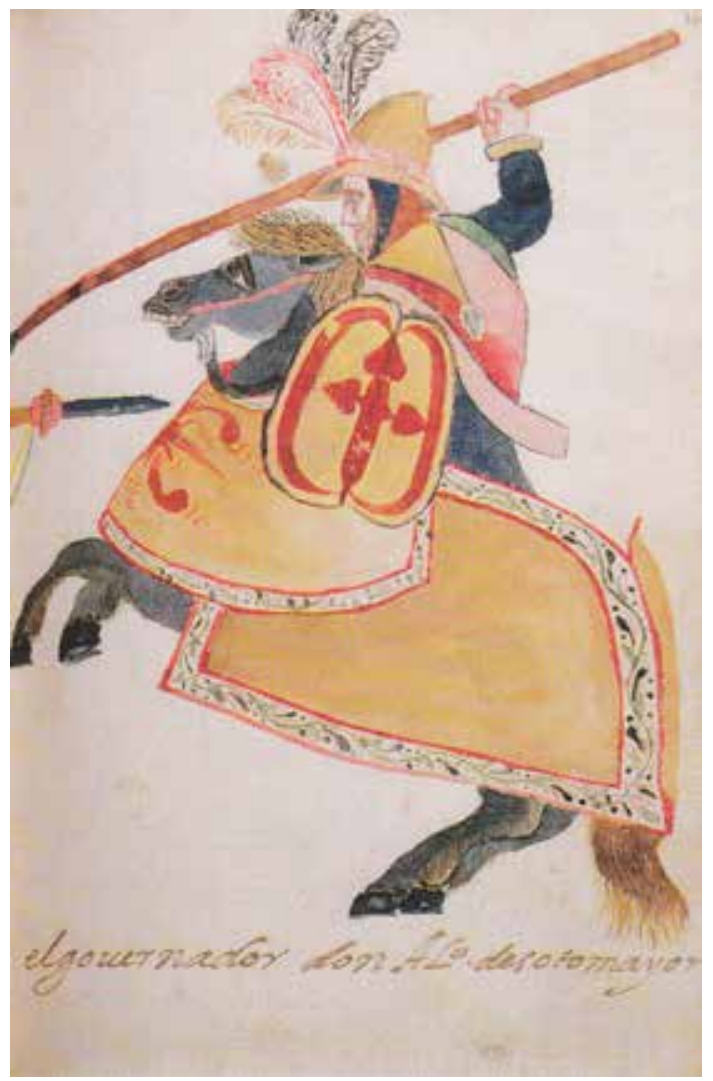

Figura 5. Fray Diego de Ocaña. El Gobernador don Alonso de Sotomayor.

destacable. Así sucede con Guacolda, nombrada como la bella Guacolda (ver Figura 8). Ella es el equivalente femenino de Lautaro y la evocación histórica femenina en la representación visual. Destaca en la representación el peinado, el pecho izquierdo descubierto, así también ambos brazos, aparece hilando. En el texto se agrega su destreza y habilidad para correr y manejar el arco y tirar la flecha. En este punto el recuerdo de las amazonas se hace presente ${ }^{12}$. La tendencia del renacimiento de integrar a los seres maravillosos al orden natural del mundo queda ejemplificado con las amazonas, que “... después de haber recorrido Asia menor, Escitia y África, estas damas guerreras aprovecharon el descubrimiento de América para instalarse allî" (Boia 1995: 79). "Estas mujeres guerreras van a hacer su reaparición en los relatos de los cronistas de América y en los grabados que los ilustraban" (Rojas Mix 1993: 132-138). El mito clásico es actualizado por Ocaña quien identifica a un guerrero 


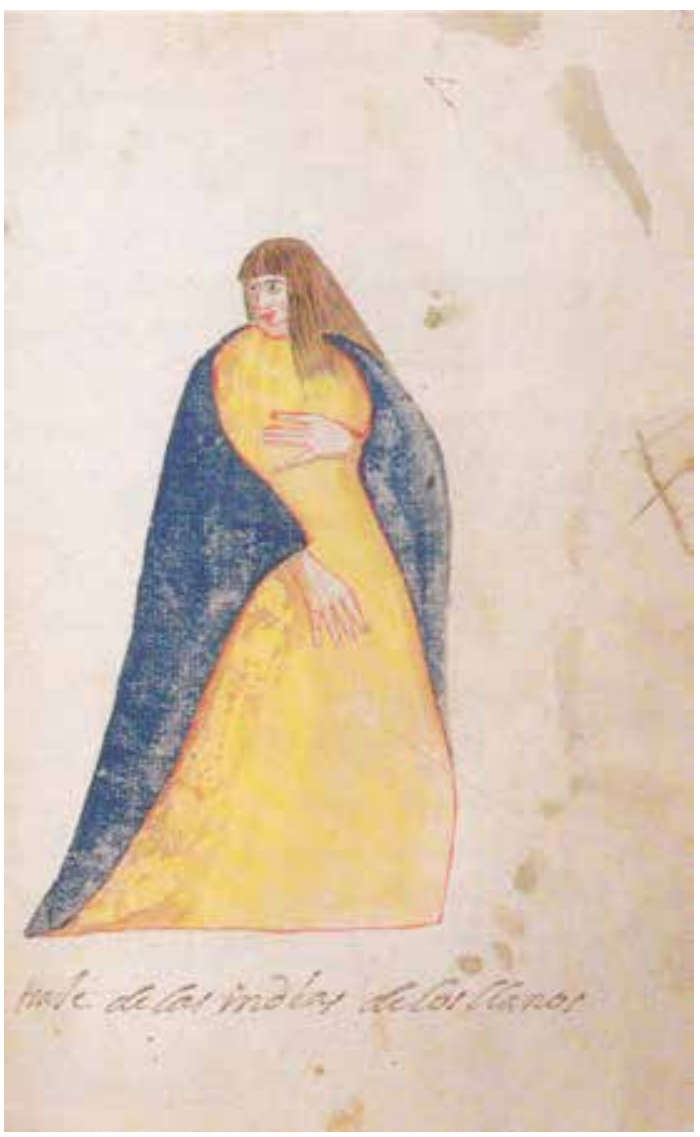

Figura 6. Fray Diego de Ocaña. Traje de las indias de los llanos.

con una compañera guerrera: Guacolda en apariencia de Amazona.

A todas luces es posible realizar un análisis de las representaciones tanto visuales como textuales según el imaginario cultural que las produce. Por ejemplo y de acuerdo a lo visto, los modelos antiguos desempeñan un papel determinante en la obra de Ocaña. Allí aparecen los gigantes y las amazonas, tanto en la representación textual como visual respectivamente. Representaciones que se cruzan y superponen en un relato de corte épico, donde la guerra o las destrezas bélicas se constituyen en protagonistas de la narración. Así, el imaginario medieval, épico, caballeresco está presente. Toda representación indígena, independientemente de su soporte (textual o visual), hace hincapié en estos aspectos. En las imágenes de indígenas e hispanos el autor consideró los elementos necesarios para darles un carácter caballeresco. La concordancia entre texto e imagen complementan y refuerzan la

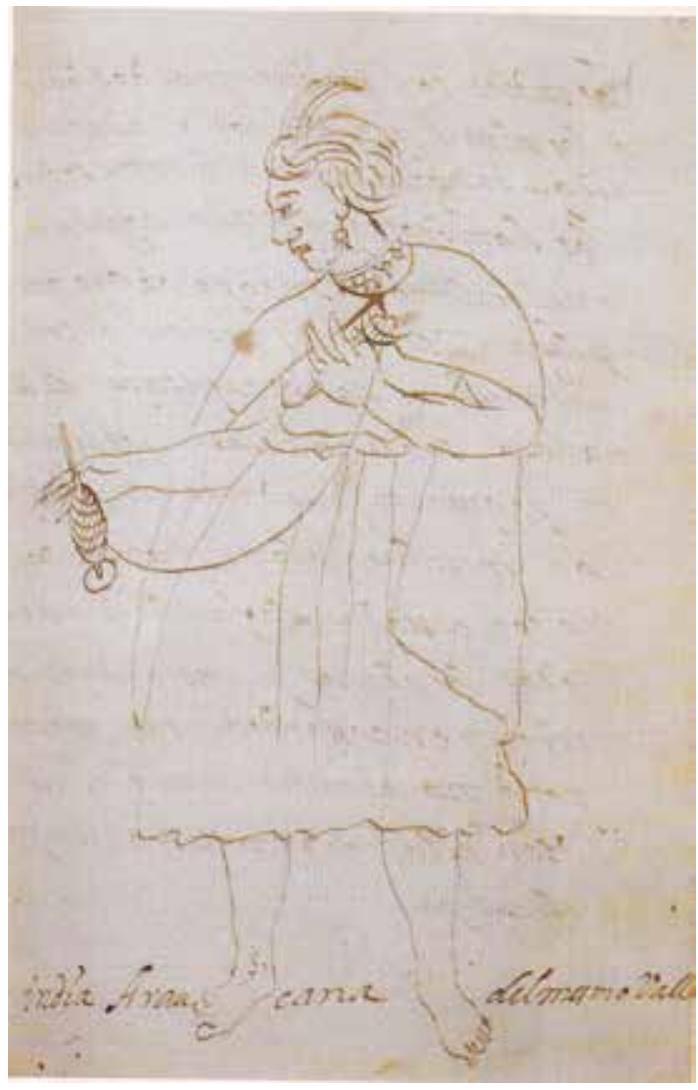

Figura 7. Fray Diego de Ocaña. India araucana del mismo valle.

idea central de la obra surgida en tierra de guerra con posterioridad a Curalaba.

De esta manera, si la representación visual del indio chileno es una representación acorde al relato épico de construcción europea y desde otra perspectiva también se integran elementos del imaginario antiguo, entonces, cabe aún preguntarse ¿Qué realidad y representación visual de alteridad se fue construyendo sobre el indio?

Incorporar las imágenes o representaciones de aquellos que no habitan en tierra de guerra, sino más bien el sector de llanos parece un buen ejercicio. Desde los llanos de Payta hasta Chile, Ocaña caracteriza al indio con una vestimenta españolizada, usa sombrero y una manta a manera de capa. Aparece descalzo, pero en el texto se advierte que en algunas ocasiones calzan sandalias como las de los franciscanos. La narración confirma la imagen y entrega detalles de peinado y cabellera, además agrega información sobre actitudes indígenas: “...y de ordinario tiene mala inclinación de no hacer cosa ninguna por bien sino es aporreándolos, y luego 


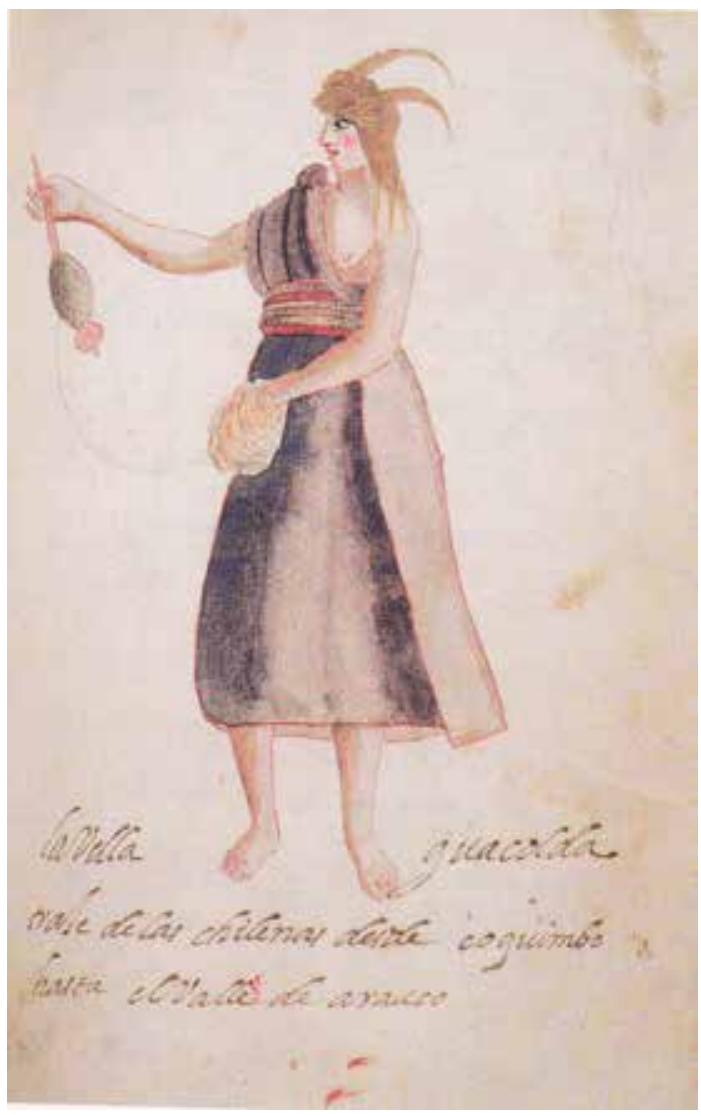

Figura 8. Fray Diego de Ocaña. La bella Guacolda. Traje de las chilenas desde Coquimbo hasta el valle de Arauco.

van lijeros y traen todo cuanto los españoles les piden..." (Ocaña 1995:56 [1600]).

Si comparamos las representaciones tanto visuales como textuales de "los indios de los llanos" (ver Figura 9) con los "indios de la ciénaga de Purén" (ver Figura 10) las diferencias son evidentes en traje, disposición, costumbres, destrezas y actitudes.

En relación a la representación femenina de las mujeres de los llanos se cumple la misma dinámica, se aprecian diferencias entre estas y las de tierra de guerra, en particular con la representación de la bella Guacolda.

Retomando la interrogante sobre la representación visual de alteridad que es posible identificar en Ocaña, es necesario recordar que en el itinerario narrativo-descriptivo, el autor se mueve en una constante tensión, la de reconocer y conocer. La necesidad de reconocer está en argumentar y verificar la fuerza e ímpetu de los indios que vencieron a los españoles en Curalaba. Ellos son guerreros

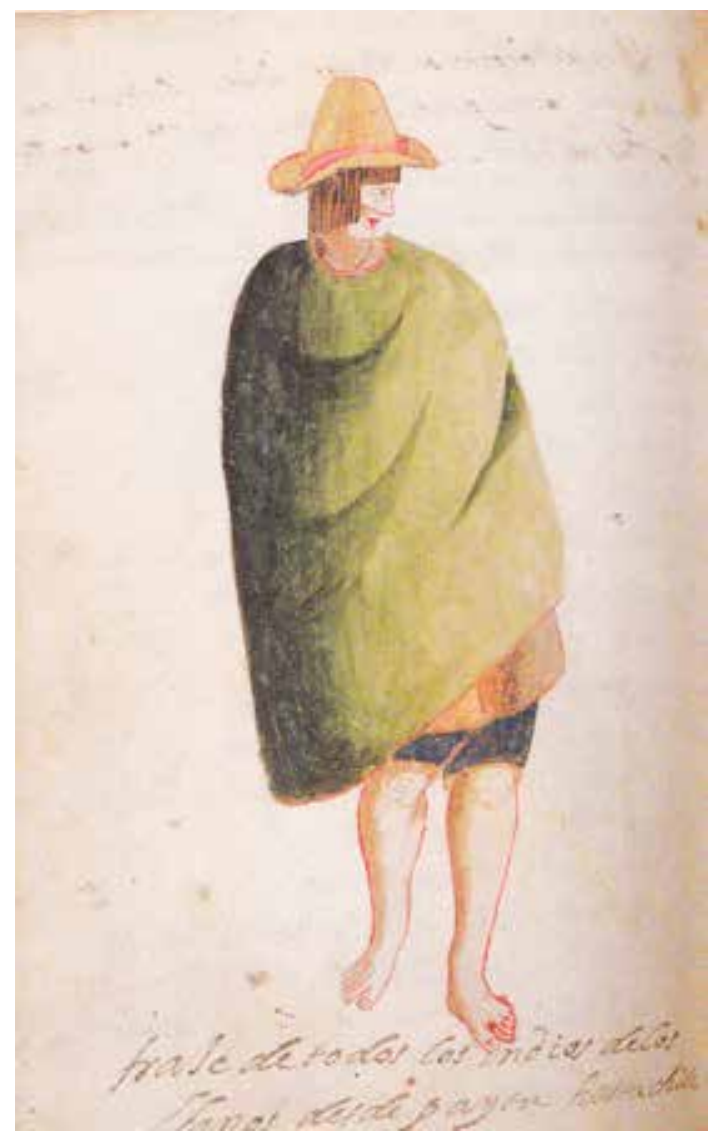

Figura 9. Fray Diego de Ocaña. Traje de todos los indios de los llanos desde Payta hasta Chile.

y ellas hábiles y diestras. Se integra además en el reconocer el recuerdo y pervivencia de los mitos de la antigüedad, los gigantes y amazonas identificados en el relato. En estas descripciones o representaciones no existe una construcción de alteridad que tenga como referente al español. Se aprecia en la representación visual la similitud entre hispanos e indígenas.

En tanto, la necesidad de conocer está dada por la constatación de otra manifestación de la realidad que escapa a la guerrera. Me refiero a la representación de los indios de los llanos (indio-india).

Ocaña aprecia diferencias, construye alteridades, pero su referente no es el hispano, el referente de construcción de alteridad es el guerrero en general (hispano o indígena). Todo aquel que no posea características guerreras es un otro. En tanto las diferencias se manifiestan al interior del propio grupo indígena, posibles de advertir tanto en la representación visual como textual. Mientras la 


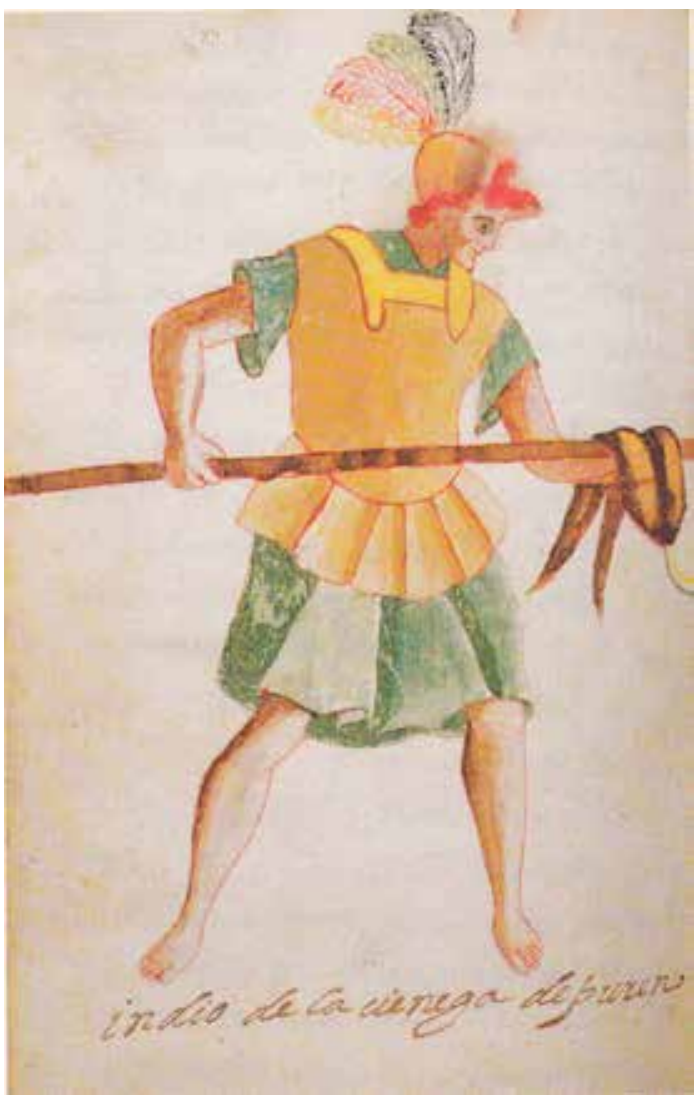

Figura 10. Fray Diego de Ocaña. Indio de la ciénaga de Purén.

india de los llanos es descrita como puerca, bruja y borracha, la india de tierra de guerra es hábil, bella y diestra. Mientras el indio de los llanos es flojo y obedece a golpes, el indio de guerra es valiente, hábil, astuto y racionalmente libertario, ya que la guerra y las aptitudes para ésta son engrandecidas y asumidas como valores de apego a la libertad y amor a la tierra.

\section{Conclusiones}

De acuerdo a lo hasta aquí planteado hemos de asumir algunas constataciones en relación a la representación indígena en la obra de Ocaña.
En primer lugar, existe en la obra de Ocaña una construcción identitaria sobre el indio que se basó en dos oposiciones binarias tanto internas (dentro del propio grupo indígena) como externas (en relación al grupo español). Por un lado, Ocaña aprecia diferencias al interior del mundo indígena y construye la alteridad teniendo como referente la guerra. Así, distingue entre los indios de los llanos, descritos textualmente como flojos y reticentes al trabajo, y los indios de tierra de guerra, los cuales los considera valientes y hábiles. La representación de los indios de los llanos y de los indios de tierra de guerra que se despliega iconográficamente también manifiesta esa diferencia. Por otra parte y como tercera constatación, se advierte que el autor homologa al indio de tierra de guerra con el colonizador español. Ambos se enfrentaron de igual a igual en la gran rebelión general indígena de fines del siglo XVI en el reino de Chile, consolidando este territorio como tierra de guerra. Por último, se distingue en este texto que la guerra y las aptitudes para esta son estimadas y sobrevaloradas. En la representación textual esta queda de manifiesto. Los indios de guerra, por ejemplo, tienen buenas costumbres porque "de ordinario se ocupan en el ejercicio de guerra, además de ser indios de mucha razón; (ya que) sustentan la guerra para no servir a los españoles..." (Ocaña 1995:58 [1600]). Así mismo, iconográficamente la representación del "indio" emula al del hispano, a la del civilizado.

\section{Agradecimientos}

Mis agradecimientos a Margarita Alvarado por la lectura de un primer manuscrito, y sus comentarios expertos, aunque la responsabilidad final me pertenece. A Rodrigo Ruz por invitarme a participar en este número. A los evaluadores de este artículo por sus comentarios y sugerencias. Al proyecto Núcleo Temático de Investigación, Relatos de viajeros: ¿los otros discursos sobre "los indios"? Universidad Academia de Humanismo Cristiano, del cual este artículo forma parte. 


\section{Referencias Citadas}

Alpers, S.

1987 El Arte de Describir. El Arte Holandés en el Siglo XVII. Blume, Madrid.

Amodio, E.

1993 Formas de la alteridad: Construcción y difusión de la imagen del indio americano en Europa durante el primer siglo de la conquista de América, Abya-Yala, Quito.

Barthes, R.

1963 La retórica de la imagen. Communications 4:29-47 París.

Boia, L.

1997 Entre el Ángel y la Bestia. Editorial Andrés Bello, Santiago.

Carreño, G.

2008 El pecado de ser otro. Análisis a algunas representaciones monstruosas del indígena americano (Siglos XVI-XVIII), Revista Chilena de Antropología Visual 12:127-146.

Fayet, A.

2006 Imágenes etnográficas de viajantes alemanes en Brasil del siglo XIX. Revista Chilena de Antropología Visual 7:31-59.

Figueroa, A. y Gallardo, V.

2008 La imagen del "indio" en Chile durante la Colonia: ¿Retrato o Discurso? Contextos 19:41-49.

Gombrich, E.

2002 Arte e Ilusión. Estudio Sobre la Psicología de la Representación Pictórica. Debate, Madrid.

González-Caniulef, E.

2015 Tendra obligación de llevar un diario de campaña: representaciones de género y etnicidad en registros documentales sobre los mapuche, durante la segunda mitad del siglo XIX. Nuevo Mundo Mundos Nuevos. http://nuevomundo.revues. org $/ 68745$

Hauser, A.

2002 Historia Social de la Literatura y el Arte. Ediciones Debate, Buenos Aires.

Iniesta Cámara, A.

2004 Camino, viaje y escritura Colonia: un caso, Diego de Ocaña. Ponencia presentada en Segundo Congreso Internacional de Literatura Argentina/ Latinoaméricana / Española. Mar del Plata, Argentina.

Jara, A

1984 Guerra y Sociedad en Chile. Editorial Universitaria, Santiago.

Lira, $M$.

2004 La representación del indio en la cartografía de América. Revista Chilena de Antropología Visual 4:86-102.

López de Mariscal, B. y Madroñal, A.

2010 Fray Diego de Ocaña. Viaje por el Nuevo Mundo: de Guadalupe a Potosí, 1599-1605. Iberoamericana, Vervuert, Bonilla Artigas Editores, Instituto Tecnológico y de Estudios Superiores de Monterrey. Madrid.
Magasich, J.

1991 América Mágica. Mitos y creencias en tiempos del descubrimiento del nuevo mundo. LOM ediciones, Santiago.

Martínez, J.L.

2011 Gente de la Tierra de Guerra. Los Lipes en las Tradiciones Andinas y el Imaginario Colonial. Fondo Editorial PUCP, DIBAM, Centro de investigaciones Diego Barros Arana, Lima/Santiago.

Martínez, N.

2000 Las Crónicas hispanas y las voces del otro. En Los Discursos Sobre los Otros (Una Propuesta Metodológica Interdisciplinaria), editado por J.L Martínez, pp. 25-61, Ediciones Facultad de Filosofía y Humanidades, Universidad de Chile. LOM Ediciones. Santiago, Chile.

Mignolo, W.

1982 Cartas, crónicas y relaciones del descubrimiento y la conquista. En Historia de la Literatura Hispanoamericana 1, editado por L.I. Madrigal, pp. 57-111 Cátedra. Madrid.

Ocaña, D.

1995 [1600] Viaje a Chile. Relación del Viaje a Chile, año de 1600. Santiago. Editorial Universitaria.

Odone, C.

2008 Sobre la visualidad del Chaco: La reproducción y la sensibilidad estética de la cacería en los Andes (s. XVIII). Revista Chilena de Antropología Visual 11: 20-35.

Olson, D.

1999 El Mundo Sobre el Papel: el Impacto de la Escritura y la Lectura en la Estructura del Conocimiento. Gedisa, Barcelona.

Pastor, B.

1984 Discurso Narrativo de la Conquista de América. Ediciones Casa de las Américas, La Habana.

Peña, B.

2011 Imágenes Contra el Olvido. El Perú Colonial en las Ilustraciones de fray Diego de Ocaña. Fondo Editorial de la Pontificia Universidad Católica del Perú, Lima.

Pereira Salas, E.

1995 Introducción. Relación del viaje a Chile, año de 1600 (Crónica de viaje). En Viaje a Chile. Relación del Viaje a Chile, año de 1600, Ocaña, D. Editorial Universitaria, Santiago.

Real Academia Española

Diccionario de Autoridades. Tomo V (1737). www.rae.es/ recursos/diccionarios/dicionarios-anteriores-1726-1996/ diccionario-de-autoridades.

Rojas Mix, M.

1993 Los monstruos: ¿mitos de legitimación de la conquista? En América Latina: Palavra, Literatura e Cultura. I, editado por A. Pizarro, pp. 123-150. Editora da Universidade Estadual de Campinas UNICAMP.

\section{Notas}

1 Para mayor información sobre Fray Diego de Ocaña, sobre sus datos biográficos y artísticos ver el artículo de José Roso Díaz, El Fraile Jerónimo Diego de Ocaña. Un apunte sobre devoción mariana, arte y literatura en la América hispana del Barroco. En Anuario de Estudios Filológicos, 2008, volumen XXXI, pp. 195-208. 
2 El siglo XVI terminó en una sublevación general indígena, precipitada por el ataque sorpresa al gobernador Martín García Oñez de Loyola, en un campo llamado Curalaba a orillas del río Lumaco, en el camino desde la ciudad de Imperial a Angol. En aquel asalto el gobernador y unos cincuenta españoles perecieron. Las siete ciudades al sur de Concepción fueron destruidas y sus habitantes, si no muertos, obligados a retirarse.

3 "La relación de viaje que hizo fray Diego de Ocaña por tierras americanas entre 1599 y 1605 es un texto que ha sido publicado en forma fragmentaria en varias ocasiones, dos de ellas por fray Arturo Álvarez, la primera con el título Un viaje fascinante por la América hispana del siglo XVI (Madrid, Studium, 1969) y la segunda, aún más fragmentada que la primera, titulada $A$ través de la América del Sur, forma parte de la colección "Crónicas de América" de Historia 16 (Madrid, 1987). Existe un tercer fragmento de este texto que bajo el título "Fray Diego de Ocaña, Relación del viaje a Chile, año 1600" fue publicada en dos ocasiones por Eugenio Pereira Salas, la primera en Anales de la Universidad de Chile y la segunda, ya en forma de libro, con un prólogo de Lorena Loyola Goich, en 1995, en la Editorial Universitaria" (Blanca López de Mariscal 2010: 16). Destacamos aquí la edición de Blanca López de Mariscal y Abraham Madroñal, como la primera edición completa de este texto, la cual incluye un estudio crítico del relato de viaje que realizó Fray Diego de Ocaña. La obra se titula Fray Diego de Ocaña. Viaje por el nuevo mundo: de Guadalupe a Potosí, 1599-1605, publicada por Editorial Iberoamericana, Vervuert, Bonilla Artigas, Instituto Tecnológico y de Estudios Superiores de Monterrey, 2010.

4 Según López de Mariscal y Madroñal, fray Diego de Ocaña tenía por costumbre ir anotando en cualquier papel las circunstancias de cada jornada y, muy especialmente, todo lo que afectaba a la economía relacionada con el culto a la Virgen (López de Mariscal et al. 2010: 14-15).

5 Las anotaciones de cronistas, viajeros, exploradores sin duda constituyen un material de reconocimiento de alteridad, esto se hace más evidente con la profusión de testimonios en los siglos siguientes. Al respecto la antropóloga Elsa González-Caniulef señala: "El diario de campaña, la bitácora del científico, las notas o el cuaderno del viajero, los informes de exploración, las memorias históricas, entre toda aquella cuantiosa sumatoria que constituye la producción intelectual elaborada durante el siglo XIX, en Chile conforman diversas prácticas que a la vista actual es posible denominar como etnográficas; a pesar que como disciplina la antropología aún se encontraba en ciernes". Elsa Gabriela González-Caniulef. 2015. Tendra obligación de llevar un diario de campaña: representaciones de género y etnicidad en registros documentales sobre los mapuche, durante la segunda mitad del siglo XIX. Nuevo Mundo Mundos Nuevos.

6 Los acontecimientos bélicos son el motivo preferencial en las crónicas del siglo XVII. En ellos incluimos las batallas, paces o parlamentos y también las que representan la intervención divina que viene a socorrer al ejército español. En todos los casos se ilustran tanto ejércitos indio como español, que aparecen conformando "masas". Los indios se distinguen por sus vestimentas, falta de cascos, lanzas; por lo general los españoles lo hacen por sus armaduras, el uso de caballos y de armas de fuego. Lo que hemos denominado costumbres es el tema más recurrente en este tipo de documentos. De entre ellas, diversos juegos y modo de lacear son motivos que se repiten. En todos ellos solo aparecen figuras masculinas (es exclusivamente Ocaña quien ilustra mujeres) y siempre con el mismo elemento característico: un tocado en la cabeza (América Figueroa et al. 2005).

7 Beatriz Pastor señala varios discursos simultáneos al referirse al discurso narrativo de la conquista. La autora identifica a lo menos tres tipos: mitificador, del fracaso, de la rebelión. En este esquema José Luis Martínez, identifica dos planos distintos, el del discurso narrativo de la conquista como una gran unidad que organiza y da sentido a las descripciones y los otros tres discursos que el autor define como discursividades, es decir como formas específicas que adquieren los discursos, en una estructura social concreta y en una coyuntura histórica determinada (Pastor 1983; Martínez 2011).

8 Para profundizar sobre las primeras representaciones iconográficas de los habitantes de América existe una amplia bibliografía, destacamos a Jorge Magasich con su texto América Mágica. Mitos y creencias en tiempos del descubrimiento del nuevo mundo, Emanuele Amodio. Formas de la alteridad: Construcción y difusión de la imagen del indio americano en Europa durante el primer siglo de la conquista de América, Gastón Carreño. "El pecado de ser otro. Análisis a algunas representaciones monstruosas del indígena americano (siglos XVI-XVIII)".

9 La obra completa de Fray Diego de Ocaña contiene veintidós imágenes y cinco mapas, en nuestra investigación trabajaremos en específico con 10 de ellas, las cuales se vinculan en específico con la historia colonial de Chile. El manuscrito original de la obra de Fray Diego de Ocaña se encuentra en la Biblioteca Museo de la Universidad de Oviedo, por no poder tener acceso a dicho original las imágenes que aquí se reproducen son copia de la edición de 1995 de la Editorial Universitaria.

10 Ver figura 10, la última de la presentación, Indio de la ciénaga de Purén.

11 Beatriz Peña advierte que Ocaña al conocer las historias de valentía y belicosidad de los indígenas, logra admiración por estos e identifica y representa a Lautaro de la misma forma que los soldados españoles (Peña 2011).

12 Sobre este punto, no coincidimos con Beatriz Peña, quien sostiene que, por su condición de religioso, Ocaña evitó la representación de indígenas desnudos y en específico para las mujeres la desnudez representaría el pecado. A su juicio la representación femenina fue abordada simbólicamente como la presencia del mal (Peña 2011). 
